\title{
Închisorile ieromonahului Mina Dobzeu
}

\author{
Adrian Nicolae PETCU*
}

\begin{abstract}
Mina Dobzeu is known in the Romanian postcommunist imagery as the priest who baptized Jewish writer and political prisoner Nicolae Steinhardt in the Christian Orthodox faith inside the Jilava prison. However, Mina Dobzeu was, most of all, one of those Romanian Orthodox spiritual fathers who fought against Communist atheism not necessarily through sermons, but mostly through samizdat. Through manifests (as he did in 1948), or letters sent to the leadership of the Romanian Orthodox Church in 1959, or to Nicolae Ceaușescu in the 1980s, father Mina Dobzeu demanded that atheism be no longer indoctrinated to young people, and the manifestation of religious freedom be ensured. In order to discover the entire activity of father Mina, both as religious servant and preacher and as a fighter for the freedom of faith, we initiated an extensive research in the archives of both the former political police and the church, managing to re-trace the journey of this authentic confessor of Orthodoxy under the
\end{abstract} Romanian communist persecution.

Keywords: communist repression, orthodox monasticism, state-church relations during communism.

\section{Introducere}

Mina Dobzeu este unul dintre numeroșii clerici ortodocşi români care în perioada regimului comunist a cunoscut abuzurile, temniţa, persecuţia şi mai ales represiunea din partea poliţiei politice.

\footnotetext{
* Consilier superior în cadrul Direcției Cercetare, Editare din Consiliul Național pentru Studierea Arhivelor Securității (CNSAS) București, România.
} 
Totodată, Mina Dobzeu este un caz atipic, deoarece se situează între puţinii care au ales manifestul ca formă de opoziţie la adresa regimului ateist. A făcut acest lucru în februarie 1948, când a lipit un manifest scris în mai multe exemplare pe gardurile unor cetăţeni din satul Brădiceşti (azi în jud. Iaşi), în mai 1959 când a trimis o epistolă în 13 exemplare către ierarhii Bisericii Ortodoxe Române, prin care cerea să nu se colaboreze cu regimul politic care doreşte distrugerea Bisericii, apoi în anii 1986-1988, când a adresat din nou scrisori, de data aceasta conducerii de partid şi de stat, prin care cerea libertate de credinţă şi stoparea promovării darwinismului şi ateismului.

Această formă de opoziție anticomunistă este cunoscută în istoriografia de profil ca specifică perioadei în care s-au manifestat disidenţii din PCR, adică începând cu anii '70. Or, avem un caz de cleric ortodox, care nu era membru al Partidului Comunist, ci călugăr şi chiar printre puţinii care și-au manifestat opoziția faţă de regimul comunist în toată perioada sa de existență.

\section{Surse}

Când am iniţiat acest proiect de cercetare, ne-am propus să ajungem la arhive. Altfel spus, am cercetat arhivele fostei Securităţi, cu dosarele penale şi cel de urmărire informativă, care conţin atât perioadele legate de anchetele penale, condamnări şi detenţii, cât şi documente importante privind activitatea ieromonahului Mina Dobzeu acolo unde a slujit, la Brădiceşti, Jimbor şi Huşi.

Evident că documentele create de fosta poliţie politică nu ne-au creat un orizont documentar cuprinzător, deoarece multe aspecte legate de viaţa şi activitatea părintelui se regăsesc mai mult în arhivele bisericeşti. În acest sens, am întreprins câteva stagii de documentare în arhive mai puţin cercetate până acum, adică la Mitropolia Clujului, Arhiepiscopia Romanului şi Bacăului, Episcopia Huşilor ${ }^{1}$, Protoieria ortodoxă din Dej,

1 Aducem mulțumirile noastre Părintelui Cătălin Nicolae Luchian, de la Parohia Tomești-Deal, jud. Iaşi, pentru colaborarea depusă în activitatea de identificare 
Seminarul Teologic Neamţ şi chiar la Jimbor, parohia în care părintele Mina a slujit după detenţie. A fost un efort investigator mare, dar folositor şi cuprinzător, deoarece aşa am depistat numeroase necunoscute sau am spulberat multe confuzii care se vehiculau în biografia părintelui Mina, atât cât se scrisese până acum. Alături de Jurnalul fericirii al lui Nicolae Steinhardt în care găsim descris cu lux de amănunte etapele premergătoare şi momentul botezului viitorului monah de la Rohia, mai sunt câteva scrieri cu caracter biografic, unele documentate, precum cea a istoricului Costin $\mathrm{Clit}^{2}$ sau numeroase interviuri luate şi mărturii date de părintele Mina Dobzeu, din care unele cu un bogat bagaj informaţional şi cu profunde abordări de ordin teologic ${ }^{3}$.

a documentelor din arhivele Arhiepiscopiei Romanului şi Bacăului, de la Episcopia Huşilor și Seminarul Teologic Neamț.

${ }^{2}$ Costin Clit, Mănăstirea Brădiceşti, Iaşi, Edit. Doxologia, 2013, p. 223-225.

${ }^{3}$ Menţionăm aici: Mina DoBzeU, ,Prin pronia divină Nicolae Steinhardt este o mână întinsă către intelectuali”, în Vestitorul Ortodoxiei, an IX, nr. 177-178, aprilie 1997, p. 2; Mina DoBZEU, Trei strigări împotriva lui Antihrist. Istoria adevărată a pustnicului de la Brădiceşti, Edit. Anastasia, 1999; The Imprisoned Church. Romania, 1944-1989, INST, Bucharest, 1999, p. 154; Mina Dobzeu, Am fost duhovnicul lui Ceauşescu, ed. îngr. şi cuvânt înainte de Fabian Anton, Cluj-Napoca, Edit. Dacia, [2002]; Părintele Teofil PĂRĂIAn, Amintiri despre duhovnicii pe care $i$-am cunoscut, Cluj-Napoca, Edit. Teognost, 2003; Vasile IANCU, Interviu. „Balaurul roşu de la Răsărit a $\begin{array}{llll}\text { venit", } \quad \text { în } \quad \text { România } & \text { literară, } & \text { 3/2008 }\end{array}$ (http://arhiva.romlit.ro/index.pl/arhimandritul_mina_dobzeubalaurul_rou_de _la_rsrit_a_venit?caut=balaurul\%20rosu, consultat la 02.10.2019); a se vedea numărul dedicat părintelui Mina în revista Rost, an VI, nr. 65, iulie 2008, în care au semnat Răzvan CODRESCU, „Părintele Mina Dobzeu. Cu Steinhardt şi dincolo de Steinhardt” (p. 36-39) şi Mina DoBZEU, „În temniţele Satanei. Întâlnirea cu N. Steinhardt" (p. 40-43); Călin Emilian CIRA, Convorbiri despre N. Steinhardt, prefaţă de Ion Pintea, Cluj-Napoca, Edit. Eikon, 2010; Mina DoBzEU, Apocalipsa-planul de salvare a lumii în 7 etape, Făgăraş, Edit. Agaton, 2011; C. CliT, Mănăstirea Brădiceşti, p. 223-237; Silviu B. Moldovan, „Mina Dobzeu între răspândirea de «manifeste subversive» şi «subversiune» prin manifestare în Spirit", în vol. Despre «baltici». Ipostaze ale represiunii politice în România postbelică , Bucureşti, Edit. Eikon, 2018, p. 229-238. 


\section{Intrarea în monahism}

Mina Mihail Dobzeu s-a născut la 5 noiembrie 1921 în localitatea Grozeşti, jud. Lăpuşna. Asupra datei de naştere există o confuzie datorată probabil zilei în care s-a înregistrat naşterea, adică la 8 noiembrie 4 . La vârsta de şase ani învaţă să citească pe acatistul Sf. Pantelimon, tipărit cu litere chirilice ${ }^{5}$.

După cum afirmă în memoriile sale, părintele Mina a intrat în monahism încă din adolescenţă, determinat de tatăl său şi fascinat de râvna misionară a preotului Vasile Prisăcaru, originar din satul său natal. După absolvirea şcolii primare din localitatea natală (1935) ${ }^{6}$, ajunge frate în mănăstirea Hâncu (25 martie 1935), jud. Lăpuşna. De aici, în 1937, viitorul ieromonah Mina Dobzeu pleacă la mănăstirea Căldăruşani, de lângă Bucureşti, unde urmează cursurile Şcolii de arte şi meserii pentru monahi, Secţia sculptură. După recăpătarea Basarabiei, tânărul Mihail Dobzeu revine la Hâncu (1941), până la refugiul din 1944. În această perioadă a încercat să se înscrie la seminarul teologic, dar nu a putut din cauza bolii de care suferea (malarie). La praznicul Bunei Vestiri, împreună cu obştea mănăstirii Hâncu, tânărul frate Dobzeu este nevoit să se refugieze, ajungând la mănăstirea Balaciu, jud. Ialomiţa, după cum avea să mărturisească mai târziu: „Când deja veneau bolşevicii peste noi, ne-am refugiat în România. Eram zece călugări, cu tot cu părintele stareţ. Am mers douăzeci de zile fără pauză, până am ajuns în Ialomiţa, doar cu o căruţă cu cai şi un car cu patru boi""7. De aici, este mobilizat în Regimentul I Artilerie Timişoara (1944-1945), luptând în Banat şi în Ungaria. Revine la

4 AEH, fond Schitul Brădiceşti, dosar 1/1946, f. nenum (extras din 1938, din registrul mitrical). Aici tatăl apare cu numele de „Diomid”, precum în toate actele civile ale părintelui Mina (Ibidem).

${ }^{5}$ Mina Dobzeu, Am fost duhovnicul lui Ceauşescu, p. 36.

${ }^{6}$ A.Prot.Dej, Dosar personal Mina Dobzeu-Parohia Jimbor, f. nenum. Se pare că o perioadă de timp a vieţuit la mănăstirea Vărzăreşti, jud. Lăpuşna (C. CLIT, Mănăstirea Brădiceşti, p. 224).

${ }^{7}$ Apud C. CLIT, Mănăstirea Brădiceşti, p. 224. 
mănăstirea Balaciu, unde se afla în refugiu Şcoala de Cântăreţi Bisericeşti de la Cernavodă, pe care o va absolvi în iunie 1946. Aici are ascultarea de cântăreț ${ }^{8}$.

De aici, alături de alţi doi călugări basarabeni (Dosoftei Sofianu şi Gamaliel Cimpoeşu) în frunte cu ieromonahul Iachint Ciobanu9 ${ }^{9}$, la 29 iunie 1946 Mihail Dobzeu ajunge în schitul de la Brădiceşti din Eparhia neobositului Episcop Grigorie Leu. Chiriarhul huşean îl remarcă pe tânărul aspirant în vieţuirea monahicească şi îl aşază în nou-refăcutul schit de la Brădiceşti cu ascultarea de cântăreţ (26 august 1946), apoi îl tunde ca monah cu numele de „Mina” în catedrala eparhială din Huşi (27 decembrie 1946). Datorită pregătirii sale şi râvnei în vieţuirea monahicească, Episcopul Grigorie al Huşilor îl va hirotoni ca ierodiacon pe seama Schitului Brădiceşti (29 iunie 1947) ${ }^{10}$.

Schitul Brădiceşti, veche vatră monahală, se aflase sub ascultarea directă a Episcopului de Huşi, ca reşedinţă episcopală (1691). La secularizare, schitul a fost desfiinţat, apoi biserica transformată în lăcaş de enorie. În 1946, când Episcopul a hotărât redeschiderea schitului, biserica a redevenit lăcaş monahal doar peste săptămână, la sărbători şi duminici trebuind să deservească pe

${ }^{8}$ AEH, fond Schitul Brădiceşti, dosar 1/1946, f. nenum; ACNSAS, fond Informativ, dosar 181347, vol. 6, f. 108; IDEM, fond Penal, dosar 21363, vol. 1, f. 7.

9 Iachint Ioan Ciobanu, n. la 28 iunie 1896, Ciuciuleni, jud. Lăpuşna, tuns în monahism la 15 august (26 octombrie) 1923 pe seama mănăstirii Hâncu, jud. Lăpuşna, hirotonit ierodiacon la 14 octombrie 1925 şi ieromonah la 2 mai 1932, hirotesit protosinghel şi numit stareț al mănăstirii de metanie la 1 octombrie 1939; absolvent al şcolii de cântăreţi bisericeşti; în 1944 s-a refugiat peste Prut, ajungând la 1 februarie 1946 ieromonah la Mănăstirea Dobrovăţ; la 3 iunie 1991 a decedat, fiind înmormântat în cimitirul „Sf. Toma” din Huşi; Dosoftei Dimitrie Sofianu n. 17 octombrie 1884, Cărpineni, jud. Lăpuşna; a intrat în monahism la 10 martie 1921 la mănăstirea Hâncu; după refugiul din 1944 a ajuns la mănăstirile Balaciu, Dobrovăţ, respectiv Brădiceşti; Gamaliel Grigorie Cimpoeşu n. 10 august (8 noiembrie) 1910, Stolniceni, jud Lăpuşna; a intrat în monahism la 2(3) martie 1939 la Episcopia Constanţei, ulterior ajungând la mănăstirile Hâncu, Căldăruşani, respectiv Brădiceşti ( $\mathrm{AEH}$, fond Schitul Brădiceşti, dosar 1/1946, f. nenum; ANIC, fond Ministerul Cultelor şi ArtelorDirecţia Studii, dosar 22/1951, f. 87).

${ }^{10}$ AEH, fond Schitul Brădiceşti, dosar 1/1946, ff. nenum. 
credincioşi, iar monahii să participe la slujbe în sobor cu preotul paroh din localitate, Vasile Pivniceru. De asemenea, slujbele pentru sfinţiri de ape, botezuri, molifte de 40 de zile, cununii şi înmormântări erau în atribuţiile parohuluii ${ }^{11}$.

\section{Prima arestare și condamnare}

Abia fusese declarată Republica Populară Română şi noul regim politic se pregătea de alegeri pentru Marea Adunare Naţională. În mod evident, era o formă de legitimare, chiar dacă fuseseră excluşi acei alegători care cunoscuseră epurarea sau o altă formă de sancţionare juridică din considerente politice. În acest fel era cât se poate de clar că noul regim politic urmează modelul ideologic sovietic. Între mulţii români care considerau că noul regim atentează la ştirbirea libertăţii de credinţă şi promovează ateismul s-a numărat şi ierodiaconul Mina Dobzeu de la Schitul Brădiceşti.

În esenţă, gestul său de opoziţie nu era de natură politică, ci avea în vedere păstrarea libertăţii de credinţă, ameninţată de măsurile care se preconizau a fi luate. Ca monah nu putea să meargă în piaţa publică să manifeste. În schimb, ierodiaconul Mina a lansat un manifest în satul Brădicești, cu titlul „Adevărul”, în care a denunţat politica ateistă a guvernului comunist şi a încurajat pe credincioşi să-şi păstreze credinţa şi să o cultive inclusiv copiilor lor.

Manifestul în cauză era o bucată de hârtie scrisă de ierodiaconul Mina Dobzeu şi multiplicată la indigo în şapte exemplare, pe care le-a lipit pe câteva garduri din satul Brădiceşti în ziua de 28 februarie 1948. Cei vizaţi erau credincioşii îndemnaţi de autor să se ferească de ,învăţătura marxist-leninistă” al cărei purtător era noul regim de ,democraţie-populară”. Ierodiaconul Mina considera că noul regim politic vrea să distrugă „opera lui Dumnezeu, creştinismul” şi cultivă pe ,tatăl minciunii, Satana”. Ca reacţie la politica distructivă la adresa Bisericii, autorul cerea

\section{${ }^{11}$ Ibidem.}


credincioşilor să-şi educe copiii încât să „,rămână ţărani în credinţa adevărată" 12 .

Câteva luni, cazul de la Brădicești a rămas fără autor, bănuit însă de organele de ordine a fi ,din apropierea cercurilor bisericești”"13. La 19 iunie 1948, Inspectoratul de Siguranţă Iaşi raporta Direcţiei Generale de Siguranţă că la începutul lunii februarie 1948 Episcopul Grigorie Leu vizitase satul Avereşti, aflat în apropierea Schitului Brădiceşti, unde se întâlnise cu preoţi, învăţători şi administratori de moşii, cunoscuţi ca foşti membri în PNŢ şi cu atitudini ostile la adresa regimului. Se mai arăta că episcopul fusese însoţit de fiul său, preotul Vasile Leu, funcţionar la Ministerul Cultelor, care lansează „ştiri în cercuri intime"14.

Totul se petrecea într-o perioadă dificilă pentru Episcopul Grigorie Leu, din cauza presiunilor care veneau dinspre autorităţile comuniste în încercarea de a-1 determina să colaboreze cu regimul de ,democraţie-populară”. Mai ales din septembrie 1948, chiriarhul huşean era portretizat în documentele Securităţii ca un personaj de modă veche, care refuza să se angreneze în acţiunile statului, pe motiv că se înconjura de funcţionari şi preoţi „reacţionari”, dar şi pentru faptul că îi ţinea aproape pe foştii reprezentanţi ai ,partidelor burgheze”, membri în Adunarea eparhială. Era arătat cu ,activitate antidemocratică”, deoarece se îngrijea de catehizarea tinerilor, difuza calendarul religios fără acordul partidului şi refuza să cedeze statului sesia eparhială. Din aceste considerente, autorităţile statului au trecut de la presiune la represiune. Au fost arestaţi consilierul referent preotul Gheorghe Penişoară şi administratorul eparhial Vasile Barbău. În consecinţă, Episcopul a intervenit la comandantul Legiunii de jandarmi (3 noiembrie) şi la prim-ministrul Petru Groza (12 noiembrie) pentru eliberarea acestora ${ }^{15}$.

12 ACNSAS, fond Informativ, dosar 181347, vol. 3, f. 199.

${ }^{13}$ IDEM, fond Penal, dosar 21363, vol. 1, f. 1.

${ }^{14}$ IDEM, fond Informativ, dosar 4049, vol. 2, f. 18.

15 Pentru această problematică a se vedea: Adrian Nicolae PETCU, Nicolae Cătălin LuCHIAN (eds.), Episcopul Grigorie Leu în vâltoarea istoriei. Documente (1924-1949), Iaşi, Edit. Doxologia, 2019, doc. 312-333, p. 743-769. 
Ultima intervenţie se pare că a avut succes, deoarece Vasile Barbău a fost eliberat la câteva zile. La puţin timp, acesta a mers la Schitul Brădiceşti, unde în ziua de 19 noiembrie 1948 a fost găsit la o descindere a Securităţii întreprinsă de comandantul Ştefan Bucur $^{16}$. Motivaţia prezenţei organelor de represiune era una obişnuită atunci când se căuta incriminarea politică a unei persoane: ,pentru a găsi armament, muniţiuni şi diferite materiale ce interesează Securitatea Poporului"17, adică orice ar putea fi considerat corp delict.

Organele de represiune nu au găsit arme/muniţii, ci câteva „cărţi interzise”, considerate corpuri delicte (Nichifor Crainic, Nostalgia paradisului şi Gh. Dumitriu, Iudaism, comunism şi francmasonerie), probabil uitate de la fosta bibliotecă parohială. De asemenea, înscrisurile care aparţineau părintelui Mina Dobzeu, un caiet de meditaţii teologice şi foi volante cu predici, au atras atenţia securiştilor. Probabil că vor fi avut indicii, deoarece securiştii s-au oprit la tipul de scriere al părintelui Mina, iar în urma unei probe de scris s-au convins că el este autorul manifestului „Adevărul”.

Astfel, cercetarea penală se concentrează pe ierodiaconul Mina Dobzeu, care este reţinut la Securitatea din Huşi. În prima declaraţie consemnată, din 21 noiembrie, monahul oferă câteva detalii biografice şi este chestionat asupra unor relaţii cu foşti membri ai organizaţiei legionare, pe care le respinge în mod categoric. Anchetatorii căutau astfel o motivaţie ideologică la gestul monahului Mina de a scrie şi a difuza manifestu $1^{18}$. Aceasta a fost doar o încercare a anchetatorilor de a situa cazul Dobzeu în perspectivă ideologică, deoarece în anchetă se va căuta o legătură a

16 ACNSAS, fond Informativ, dosar 181347, vol. 9, f. 155. Într-o însemnare pe care am găsit-o în arhiva personală, părintele Mina spune: „Şeful Securităţii cercetează şi cere informaţii de la administratorul Episcopiei să-l informeze dacă Episcopul Grigorie ştie de protestul meu. Administratorul V. Barbău, cât ştia sau nu ştia de protestul meu scris, dar îl însoţeşte pe comandantul Securităţii, Bucur, şi vine la Schitul Brădiceşti, unde mă arestează (AEH, fond personal Mina Dobzeu, dosar 21, f. nenum.).

${ }^{17}$ ACNSAS, fond Penal, dosar 21363, vol. 1, f. 5.

${ }^{18}$ Ibidem, f. 7. 
reţinutului cu Episcopul Grigorie Leu. De altfel, în câteva însemnări ale sale, părintele Mina spune: „În anchetă mă presa ca să spun că în aceasta este implicat şi Episcopul Grigorie"19.

În acest context tot mai sumbru, deşi îl aprecia pe ierodiaconul Mina, episcopul se declara neputincios faţă de situaţia în care se afla acesta, după cum afirma la 28 noiembrie 1948: „îl ştiam cam slăbuţ pe Dobzeu, dar îmi pare bine că este un bun creştin; nu pot să intervin pentru el, deoarece acum nu e cazul"20. Însă, în mod evident cu acordul episcopului, două zile mai târziu, călugărul Silvan Costiuc de la Episcopie i-a dus hrană şi îmbrăcăminte ierodiaconului Mina în arestul Securităţii. Securitatea află şi, în consecinţă, trece la reţinerea gardianului Cojocaru Ilie şi a diaconului Silvan Costiuc ${ }^{21}$.

După mai bine de două săptămâni, ancheta în cazul ierodiaconului Mina Dobzeu stagna, chiar dacă fuseseră anchetaţi cei care îl ajutaseră în primele zile de detenţie. Din acest motiv, la 8 decembrie 1948, Direcţia Regională de Securitate Iaşi ordona Securităţii Fălciu ca ,ancheta sus-numitului să fie adâncită”, adică să scoată de la el informaţii cu privire la paternitatea instigării care a generat scrierea şi difuzarea manifestului, nominalizarea

${ }^{19} \mathrm{AEH}$, fond personal Mina Dobzeu, dosar 21, f. nenum.

${ }^{20}$ ACNSAS, fond Informativ, dosar 4049, vol. 2, f. 201.

21 IDEM, fond Penal, dosar 21363, vol. 1, f. 93; IDEM, fond Informativ, dosar 181347, vol. 1, f. 2. Silvan Sava Costiuc, n. 25 aprilie 1925, în Sadaclia, jud. Tighina; după şcoala primară, a urmat Seminarul teologic din Chişinău (19361940); în 1940 se refugiază la Galaţi, intrând ca frate la mănăstirea Cocoş; tuns în monahism cu numele de Silvan în obştea Catedralei episcopale din Cluj, doi ani mai târziu fiind hirotonit diacon la Catedrala din Galaţi; îşi continuă studiile la Seminarul teologic de la Neamţ (1955-1958); în 1958 hirotonit preot la Cluj, pe seama parohiei Cisteiu de Mureş, jud. Alba, până în 1969, în această perioadă urmând Institutul teologic din Sibiu; preot la Cunţa Sibiului, jud. Alba (1969-1972); stareţ la mănăstirea Cocoş din 1972, până la 15 mai 1981; preot la Parohia Curteni, jud. Mureş, de la 1 iulie 1981 (Ibidem, vol. 6, f. 69). Ulterior, se pare din cauza unor intrigi alimentate de funcţionari de la Departamentul Cultelor, ieromonahul Costiuc ajunge să slujească la Curteni-Budeşti (septembrie 1981), iar mai apoi la Parohia Lunca Banului, ambele în jud. Vaslui (Ibidem, vol. 8, f. 16v). 
legăturilor cu persoane din rândurile fostului PNŢ şi cine 1-a mai ajutat în această acţiune ${ }^{22}$.

De asemenea, securiştii erau tot mai convinşi de relaţia apropiată între Episcopul Grigorie şi ierodiaconul Mina Dobzeu. Din acest moment se începe constituirea unui întreg scenariu în care cei doi erau vizaţi într-o conspiraţie împotriva regimului politic. Elementele constitutive erau: 1. înfiinţarea în anul 1946 de către episcop a Schitului Brădiceşti cu monahi refugiaţi din Basarabia şi consideraţi „simpatizanţi PNŢ-Maniu”; 2. relaţiile cu preoţi şi intelectuali „reacţionari” pe care Episcopul le cultiva, mai ales prin păstrarea unora în apropierea sa şi în timpul vizitelor canonice; 3 . rolul fiului său, Vasile Leu, ca funcţionar la Ministerul Cultelor şi ca unul care răspândea ştiri în cercuri intime, iar mai apoi „misiunea sa” după fuga peste hotare, deci crearea unui canal de comunicare cu exilul ${ }^{23}$.

$\mathrm{Cu}$ toate presiunile din anchetă, părintelui Mina i se mai consemnează doar două declaraţii, asemănătoare în conţinut. Alături de datele biografice, apar aspecte de ordin politic privind ostilitatea la adresa regimului comunist manifestată prin scrierea şi difuzarea manifestului, alături de legăturile pe care le avea cu Episcopul Grigorie Leu. În schimb, refuză să recunoască „dispoziţiunile sau instrucţiunile” primite de la Episcop, totodată negând implicarea unor alte persoane în acţiunea sa de protest ${ }^{24}$.

Faţă de acest rezultat, la 10 februarie 1949, Securitatea din Iaşi cere din nou aprofundarea anchetei. La 14 februarie, se raportează faptul că arestatul nu recunoaşte implicarea altei persoane în acţiunea sa şi că gestul său se motivează prin ostilitatea

${ }^{22}$ IDEM, fond Penal, dosar 21363, vol. 1, f. 10.

23 Un caz asemănător şi în aceeaşi perioadă a fost cu părintele Haralambie Vasilache de la Mănăstirea Dobrovăţ, pornind de la difuzarea unor manifeste în zona mănăstirii Dobrovăţ şi cu acelaşi set de suspiciuni (pentru detalii a se vedea Adrian Nicolae PETCU, „Închisorile Arhimandritului Vasile Vasilache", în Mărturisitori ai Ortodoxiei în timpul regimului comunist. Studii şi evocări, Mihail-Simion SăSĂUJAN coord., Bucureşti, Edit. Cuvântul vieţii a Mitropoliei Munteniei şi Dobrogei, 2018, p. 290, nota 55).

${ }^{24}$ ACNSAS, fond Penal, dosar 21363, vol. 1, ff. 15-15v. 
pe care o poartă faţă de ideologia ateistă a regimului „,democratpopular" 25 .

Deoarece trecuseră câteva luni de la reţinere, Episcopul Grigorie intervine pentru ierodiaconul Mina la Securitate. La 11 februarie 1949, însuşi Episcopul Grigorie Leu trimite o adresă Securităţii Huşi, prin care solicită informaţii privind evoluţia cercetărilor, motivând că a trecut o perioadă de timp mare de la data arestării, iar dacă se dovedeşte nevinovat, Mina Dobzeu ar trebui să fie eliberat ${ }^{26}$.

În aceeaşi perioadă, Direcţia Securităţii din Iaşi cere din nou Securităţii din Huşi aprofundarea anchetei, totodată trimiţând şi un model de chestionar, în care se regăseau mai vechile elemente incriminatorii, inclusiv presupusul amestec al Episcopului Grigorie $\mathrm{Leu}^{27} \mathrm{Cu}$ toate acestea, anchetatorii nu au obţinut nimic în plus de la diaconul Mina. Mai mult, în prima parte a lunii mai 1949 acesta va intra în greva foamei, considerând că este reţinut abuziv. După trei zile, este anunţat că urmează să fie trimis în justiţie ${ }^{28}$.

Un detaliu care trebuie remarcat în privinţa anchetei este legat de veridicitatea conţinutului declaraţiilor consemnate părintelui Mina. Deşi recunoştea paternitatea scrierii şi a difuzării manifestului de la Brădiceşti, declaraţiile nu sunt scrise de el, ci doar semnate. Mai mult, la dosarul penal se păstrează copii conforme, ceea ce înseamnă că la proces completul de judecată a ignorat total paternitatea înscrisurilor din declaraţii.

În 19 iulie 1949, la Tribunalul Militar Galaţi are loc procesul împotriva părintelui. La instrucţie, împotriva sa, procurorul militar reţine faptul că părintele Mina ar fi rostit predici la Schitul Brădiceşti, motiv pentru care în ziua de 19 noiembrie 1948 a fost percheziţionat de către Securitate, ocazie în care s-a descoperit faptul că era autorul manifestului din februarie acelaşi an. $\mathrm{Cu}$ toate acestea, martorul Toader Andrei a arătat: „,N-

${ }^{25}$ Ibidem, f. 25; IDEM, fond Informativ, dosar 181347, vol. 4, f. 73.

${ }^{26}$ Ibidem, f. 74.

${ }^{27}$ IDEM, fond Penal, dosar 21363, vol. 1, ff. 68-69.

${ }^{28}$ Ibidem, f. 39. 
am auzit ca inculpatul să ţină predici”. Probabil că a fost o altă încercare a Securităţii de a-l incrimina pe părintele Mina şi de alte fapte ostile la adresa regimului „democrat-popular”, mai ales că era interesată în mod direct de rezultatul procesului. $\mathrm{Cu}$ toate acestea, prin Sentinţa nr. 733 a Tribunalului Militar Galaţi, părintele Mina era condamnat la 3 luni şi o zi pentru delictul de răspândire de înscrisuri interzise, conform art. 327 Codul Penal $^{29}$.

În privinţa detenţiei sunt foarte puţine lucruri de spus, deoarece documentele persecutorului nu reflectă aspecte de acest gen. Se pare că, după încheierea anchetei, părintele Mina ar fi fost în arestul Securităţii din Iaşi, deoarece în ziua de 8 iunie 1949 el avea să fie transferat către Tribunalul Militar Galaţi din „gara Iaşi”. La momentul transferului, miliţianul care îl supraveghea i-a dat un plic cu antetul Direcţiei Generale a Miliţiei, pentru a expedia o scrisoare egumenului Iachint, prin care îl ruga să-i trimită o sumă de bani. Se pare că plicul nu a mai ajuns la destinatar, ci în mâinile Securităţii, deoarece originalul se află în dosarul penal ${ }^{30}$.

La 9 iunie, părintele Mina era încarcerat în arestul Parchetului Militar Galaţi, iar ziua de 10 iunie 1949 a fost considerată în actele penale ca dată a reţinerii până la momentul procesului. Astfel, perioada condamnării a început cu această dată, încât perioada pedepsei a expirat la 8 septembrie ${ }^{31}$. Totuşi, se pare că părintele Mina a ieşit din închisoarea Galaţi abia la 15 noiembrie 1949, când îşi primea lucrurile personale, inclusiv reverenda ${ }^{32}$.

\section{Urmarea școlii teologice}

După detenţie, ierodiaconul Mina revine la Brădiceşti. În 1952, în acest aşezământ monastic erau şase vieţuitori (protos. Iachint Ciobanu, ierom. Gamaliel Cimpoeşu, ierod. Mina Dobzeu,

${ }^{29}$ Ibidem, ff. 50, 166-167, 169; Ibidem, vol. 2, ff. 56, 66.

${ }^{30}$ Ibidem, vol. 1, f. 125.

${ }^{31}$ Ibidem, ff. 127, 134; Ibidem, vol. 2, f. 65.

${ }^{32}$ Ibidem, vol. 1, f. 132. 
ierod. Mina Agapie şi fratele Vasile Mihalachi) în frunte cu egumenul Dosoftei Sofian ${ }^{33}$. Ca fost deţinut politic, la Brădiceşti, ierodiaconul Mina avea domiciliu obligatoriu, fiind nevoit să se prezinte la postul de Miliţie de două ori pe lună $\breve{3}^{34}$. Din cauza acestui regim restrictiv, în iunie 1952 i se interzice să părăsească localitatea pentru a merge la un tratament balnear ${ }^{35}$. Restricţiile domiciliare i se vor ridica abia după înscrierea la Seminarul teologic.

La 25 august 1954, ierodiaconul Mina solicita Episcopului Teofil binecuvântarea pentru a continua pregătirea teologică prin echivalarea celor patru clase de la Şcoala de Cântăreţi bisericeşti din Constanţa cu primii doi ani de la Şcoala tehnică de Cântăreţi bisericeşti, Secţia monahală, de la mănăstirea Neamţ, în perspectiva înscrierii la Institutul teologic. Solicitarea a fost aprobată de către Episcopul Teofil, care la rândul lui a cerut acordul Patriarhiei Române, care avea în subordine seminarul nemţean ${ }^{36}$.

Mai apoi, ierodiaconul Mina era recomandat să fie hirotonit în treapta preoţească. La 3 octombrie 1955, arhimandritul Ghenadie Niţoiu trimitea o adresă Episcopului Teofil Herineanu, prin care arăta că, printre ,elevii monahi care s-au distins la învăţătură, bună purtare şi sârguinţă în ascultări şi viaţă evlavioasă este şi ierodiaconul Mina Dobzeu. [...] În mănăstire s-a supus tuturor ascultărilor la care a fost rânduit, de asemenea şi în şcoala noastră". Astfel, arhimandritul Ghenadie solicita hirotonirea ierodiaconului Mina ca ieromonah, deoarece spunea el, „fiindu-ne şi nouă de folos la organizarea slujbelor în sobor în paraclisul şcolii, precum şi la alte manifestări în cadrul Secţiei monahale"37. Drept răspuns, în ziua de 7 octombrie, Episcopul Teofil 1-a hirotonit pe ierodiaconul Mina Dobzeu ca ieromonah în Catedrala eparhială din $\operatorname{Roman}^{38}$.

33 AARB, fond Cancelarie, dosar 43/1952, f. nenum; ANIC, fond Ministerul Cultelor şi Artelor-Direcţia Studii, dosar 22/1951, ff. 2, 82, 84.

${ }^{34}$ M. DoBZEU, Trei strigări împotriva lui Antihrist, p. 18.

${ }^{35}$ ACNSAS, fond Penal, dosar 21363, vol. 1, ff. 56-57.

${ }^{36}$ AARB, fond Cancelarie, dosar 3/1954, ff. 580-581.

${ }^{37}$ Ibidem, dosar 6/1955, f. 109.

${ }^{38}$ Ibidem, ff. 109-111. 
Tot la Seminarul nemţean, ieromonahul Mina contribuie la reactivarea Atelierului de ceramică şi sculptură, unde lucrează în cadrul Secţiei de sculptură ${ }^{39}$.

Deoarece secţia monahală a Şcolii tehnice de Cântăreţi bisericeşti de la Neamţ se desfiinţase, în aprilie 1956 părintele Mina a fost nevoit să se transfere la Seminarul teologic de la Curtea de Argeş, pentru a absolvi şi ultimul an de seminar, pe care 1-a urmat din trimestrul al II-lea. Aici a continuat inclusiv specializarea în meşteşugul sculpturii, pe care o începuse la Căldăruşani şi Neamţ, pentru care a şi promovat examenele din perioada 9-12 septembrie 1957, ţinute la mănăstirea Plumbuita, secţie a Institutului Biblic ${ }^{40}$.

În anul 1957, părintele Mina a absolvit Seminarul teologic, după care s-a înscris la Institutul Teologic din Bucureşti, ca bursier al Episcopiei Romanului, unde a urmat primii doi ani, până la exmatriculare şi $\operatorname{arestare}^{41}$.

\section{A doua arestare și condamnare}

A doua arestare a părintelui Mina Dobzeu s-a datorat tot unui gest de frondă faţă de politica ateistă a regimului comunist. În contextul declanşării măsurilor de excludere a personalului monahal şi de desfiinţare a mănăstirilor însoţită de numeroase arestări iniţiate din februarie 1958, părintele Mina s-a văzut ameninţat cu eliminarea din viaţa monahală, căreia i se dedicase încă din adolescenţă. Ca student, alături de alţi monahi care urmau cursurile Institutului Teologic din Bucureşti, a discutat acest subiect în primăvara şi vara anului 1959 , perioada cea mai critică a politicii comuniste în privinţa mănăstirilor. Văzând această diminuare drastică a tot ceea ce era monahal în România acelei vremi şi considerând că acestei politici a achiesat inclusiv ierarhia Bisericii

\footnotetext{
${ }^{39}$ ASTN, dosar 4/1954, f. 155.

${ }^{40}$ Ibidem, dosar 3/1955, f. 175; A.Prot.Dej, Dosar personal Mina Dobzeu-Parohia Jimbor, f. nenum; M. Dobzeu, Trei strigări împotriva lui Antihrist, p. 51.

${ }^{41}$ AEH, fond Protoieria Huşi, dosar personal Dobzeu Mina, ff. 21-21v.
} 
Ortodoxe Române, în mai 1959, părintele Mina a redactat o scrisoare şi a expediat-o în copie manuscrisă ierarhilor ortodocşi şi conducerii Institutului Teologic din Bucureşti, în număr de 13 exemplare.

Potrivit spuselor sale, demersul a fost determinat de trei vedenii pe care le-ar fi avut, cu o mare încărcătură teologică, în timpul vacanţei de Paşti din 1959, asupra cărora nu ne propunem să insistăm, deoarece avem în vedere doar perspectiva istorică asupra subiectului. În câteva cuvinte, părintelui Mina i s-ar fi arătat sub forma unor personaje cum ierarhia ar fi acceptat să colaboreze cu statul ateist la distrugerea Bisericii.

$\mathrm{Cu}$ toate acestea, demersul părintelui Mina nu poate fi catalogat ca unul schismatic sau denigrator la adresa ierarhiei, numai şi pentru faptul că era o victimă a politicii comuniste de desfiinţare a mănăstirilor, politică refuzată de însuşi patriarhul Justinian $^{42}$.

Exemplarul trimis către Institutul Teologic a ajuns la rectorul Ion Gh. Coman, care, potrivit unui document al Securităţii, ,i-a atras atenţia ieromonahului Mina Dobzeu că nu trebuie să mai vorbească nimănui despre acest fapt" ${ }^{\prime 3}$ şi a tăinuit fapta părintelui Mina.

42 În această privinţă a se vedea Adrian Nicolae PETCU, „Decretul 410/1959 de la adoptare la aplicare", în vol. Biserică şi stat. Perspective istorice şi teologice. Studii în memoria Părintelui Profesor Adrian Gabor, V. A. CARABĂ, S. L. NAZÂRU şi I. Al. TudoRIE (eds.), Brăila, Edit. Istros, 2019, p. 523-560.

43 ACNSAS, fond Informativ, dosar 181347, vol. 4, f. 8. În acelaşi document, căpitanul de Securitate Cristea Ioan arăta că rectorul I. Gh. Coman ,sprijină şi îndrumă o serie de elemente duşmănoase şi în special călugării, asupra felului cum să-şi ascundă trecutul lor duşmănos, pentru a urma teologia”. Exprimarea nu este întâmplătoare, deoarece în documentele Securităţii din această perioadă se regăsesc numeroase pasaje de acest fel, adică mediul teologic devenise un teren de manifestare al celor care aveau un trecut ostil la adresa regimului democrat-popular, toate acestea constituind chiar un cap de acuzaţie la adresa patriarhului Justinian la sfârşitul anului 1958, când puterea comunistă cerea insistent reformarea monahismului, evident pe principiile cerute de Departamentul Cultelor (în acest sens a se vedea: Adrian Nicolae PETCU, „Decretul 410/1959 de la adoptare la aplicare”, passim). 
Totuşi, scrisoarea a mai fost interceptată. Exemplarul trimis mitropolitului Vasile Lăzărescu al Banatului a fost dat Securităţii de către sursa „Lipan Ion”44. Cel trimis mitropolitului Iustin Moisescu al Moldovei a fost interceptat de Securitatea regiunii Iaşi, care, pe motiv că are ,un conţinut duşmănos”, a întreprins o serie de verificări în cazul părintelui Mina la ordinul Direcţiei Generale de Securitate $^{45}$. O altă copie a scrisorii a fost dată Securităţii în septembrie 1953 de către informatorul „Marcu”46.

Exemplarul scrisorii trimis Episcopului Andrei Magieru a fost interceptat de către un colaborator al Departamentului Cultelor din Episcopia Aradului, care a semnalat cazul împuternicitului teritorial de Culte. Considerând că este un afront adus politicii regimului, împuternicitul a semnalat cazul centralei Departamentului Cultelor, care la rândul său a iniţiat investigaţia, care a condus la arestarea părintelui Mina.

Conform practicii autorităţilor comuniste, ceea ce a urmat trebuia să respecte măcar la suprafaţă legiuirile Bisericii şi legislaţia cu privire la culte, adică, Institutul Teologic din Bucureşti să se sesizeze, conform analizei din 29 iunie 1959 a Departamentului Cultelor: „Propunem ca tov. Inspector principal Stănescu, care controlează şi supraveghează şcolile de învăţământ religios, să analizeze acest caz împreună cu conducerea Institutului în vederea luării de măsuri corespunzătoare" 47 .

În ziua de 31 august 1959, în urma rezoluţiei prorectorului Nicolae I. Nicolaescu, în faţa profesorilor Alexandru Ciurea (catedra de Istoria Bisericii Române) şi Mircea Chialda (catedra de Studiul Vechiului şi Noului Testament la doctorat), părintele Mina şi alţi trei colegi, studenţi-monahi: Ghenadie Lupea, Neofit Smărăndoiu şi Ignatie Bararu, au dat declaraţii. Cei trei monahi au dat referinţe bune despre comportamentul duhovnicesc al părintelui Mina. El, însă, conform unui chestionar, a fost nevoit să detalieze

\footnotetext{
${ }^{44}$ ACNSAS, fond Informativ, dosar 181347, vol. 4, f. 30.

${ }^{45}$ Ibidem, ff. 32-38.

${ }^{46}$ Ibidem, ff. 40-44.

${ }^{47}$ Ibidem, ff. 14-16.
} 
asupra motivului care 1-a determinat să recurgă la gestul trimiterii scrisorii către ierarhie şi conducerea Institutului.

În urma referatului întocmit de către doi profesori de Teologie, cu rezoluţia prorectorului Nicolae Nicolaescu, la 1 septembrie s-a constituit comisia de disciplină, formată din profesorii: Gheorghe Moisescu (catedra de Istoria Bisericii Române $)^{48}$, Vladimir Prelipcean (catedra de Vechiul Testament) şi Ene Branişte (catedra de Liturgică). Aceştia au analizat declaraţiile celor patru monahi şi conţinutul scrisorii trimise de Mina Dobzeu. Astfel, s-a propus ,eliminarea definitivă din Institut a ieromonahului Mina Dobzeu din anul II”, precum şi „luarea de măsuri pentru preîntâmpinarea răspândirii ideilor greşite şi primejdioase", deoarece atât scrisoarea, cât şi declaraţia sa de la dosar sunt un ,produs al unui misticism bolnav, al unei minţi confuze, reacţionare şi cu totul ignorante în ce priveşte interpretarea Sfintei Scripturi"49.

Patru zile mai târziu, rectorul Institutului Teologic trimitea o adresă conducerii Departamentului Cultelor, prin care detalia asupra cazului Mina Dobzeu. În document se arăta că studentul monah în cauză se făcea vinovat de ,abateri grave”, adică denigrarea ierarhiei ortodoxe, ,,atitudine de vrăjmăşie faţă de bunele raporturi din Biserica Ortodoxă Română şi regimul de democraţie populară", ,interpretarea ignorantă şi eretică a unor texte din Sf. Scriptură, cu aplicare tendenţioasă la vremurile actuale" şi ,încercarea de a aduce prejudicii conducerii Institutului" ${ }^{50}$.

48 Conform unei relatări a părintelui Mina, se pare că preotul-profesor Gheorghe Moisescu i-ar fi spus: „Vei suferi ca şi Antim Ivireanul, te vor duce şi te vor extermina" (Teofil PĂRĂIAn, Amintiri despre duhovnici pe care i-am cunoscut, p. 105).

${ }^{49}$ ACNSAS, fond Informativ, dosar 181347, vol. 4, f. 19. În octombrie 1980, într-o discuţie cu preotul Gh. Penişoară, părintele Mina avea să spună despre prof. Prelipcean şi Coman ,că poartă o stimă deosebită pentru aceşti oameni de nivel superior” şi ,exprimă simpatia şi ataşamentul sincer ce le poartă” (Ibidem, vol. 9 , f. 25).

${ }^{50}$ Ibidem, vol. 4, ff. 18-18v. 
Deşi o copie a dosarului se afla la inspectorul principal Stănescu, semn că reprezentantul de la Culte s-a ocupat îndeaproape de caz, dacă nu chiar va fi fost prezent în timpul anchetei de la Institut ${ }^{51}$, totuşi, pentru a nu se abate de la birocraţia îndătinată în relaţia Biserică-Stat, rectorul I. Gh. Coman aducea la cunoştinţă Departamentului decizia conducerii Institutului, adică „sancţionarea pe linie canonic-disciplinară”. Interesant este că rectorul menţionează faptul că ,sus-numitul n-a apucat a difuza între ceilalţi studenţi ideile nesănătoase ce-1 stăpânesc". De asemenea, în adresă nu se menţionează dacă patriarhul Justinian a dat vreo decizie, mai ales că i se solicitase exercitarea acestei atribuţii chiar în aceeaşi zi ${ }^{52}$.

Două zile mai târziu, pe 7 septembrie, în urma rezoluţiei secretarului general al Departamentului, Dumitru Dogaru, dosarul în cauză a fost trimis la Ministerul Afacerilor Interne. Pe 25 septembrie, în urma unui referat alcătuit de căpitanul de Securitate Cristea Ioan, generalul de Securitate Gheorghe Pintilie aproba arestarea şi anchetarea ieromonahului Mina Dobzeu ${ }^{53}$.

Între timp, la 6 octombrie, Schitul Brădicești era desfiinţat, patrimoniul fiind trecut în administrarea Mănăstirii Bogdana ${ }^{54}$, de lângă Tg. Ocna, după ce, începând cu data de 29 septembrie 1959, părintele Mina fusese obligat să îmbrace haina civilă şi să plece în lume ${ }^{55}$. A fost primit în gazdă de către un credincios din sat, Vasile

${ }^{51}$ În referatul din 25 septembrie 1959 privind arestarea şi anchetarea părintelui Mina, căpitanul Cristea I. menţionează faptul că ancheta de la Institut s-a făcut „la indicaţia Departamentului Cultelor” (Ibidem, f. 4).

52 Ibidem, ff. 18-18v. În interogatoriul din 19 octombrie de la Securitate, părintele Mina spune că în septembrie 1959 venise la Institut pentru a da examenele la materiile la care nu fusese admis, din cauza scrisorii pe care o trimisese ierarhilor (IDEM, fond Penal, dosar 126777, vol. 1, ff. 9-10).

53 ACNSAS, fond Informativ, dosar 181347, vol. 4, ff. 2-4. Ofiţerul Cristea Ioan, lucrător în Serviciul Culte din Direcţia Generală a Securităţii Statului, a fost cel care s-a ocupat de urmărirea informativă şi anchetarea teologilor şi preoţilor din Bucureşti, atât înainte de condamnare, cât şi după (ex. a se vedea cazurile Teodor M. Popescu şi Dumitru Stăniloae).

${ }^{54}$ AARB, fond Cancelarie, dosar 2/1959, f. 361.

${ }^{55}$ Ibidem, dosar 27/1960, f. nenum. 
Vieru, rămânând astfel în apropierea aşezământului în care îşi dedicase o parte din viaţă. Deşi fusese anunţat de către miliţianul din sat că urma să fie ridicat de Securitate, a preferat să rămână în Brădicești. La 13 octombrie s-a consumat inevitabilul. Părintele Mina a fost arestat de Securitatea din Iaşi, iar la 19 octombrie trimis în ancheta de la Ministerul Afacerilor Interne, pentru infracţiunea de „uneltire contra ordinii sociale prin agitaţie contrarevoluţionară"s

La puţin timp, după încarcerare i se consemnează primul interogatoriu. Acesta a fost scurt, consemnându-se doar datele personale, faptul că a trimis scrisorile către ierarhi şi că aveau un conţinut religios ${ }^{57}$.

La 31 octombrie, Direcţia de Anchete Penale emite ordonanţa de învinuire împotriva sa, sub acuzaţia de ,uneltire contra ordinii sociale, prin agitaţie" ${ }^{58}$, tot aşa cum se enunţase în mandatul de arestare. Practic, pentru Securitate dosarul împotriva părintelui Mina avea destule probe pentru trimiterea în justiţie, însă era prea subţire şi totodată anchetatorii aveau în vedere inclusiv alte persoane din Institutul Teologic. Încă înainte de arestarea părintelui Mina, căpitanul Cristea I. întocmise o notă cu privire la clarificarea unor probleme din Institut, adică acţiunea de protejare a unor studenţi-călugări de către rectorul I. Gh. Coman şi depistarea monahilor şi profesorilor cu „concepţii misticoduşmănoase" 59 .

Aşadar, în aceeaşi zi, părintele Mina este luat din nou în anchetă. Timp de două ore i se consemnează doar o pagină, în care părintele susţine acelaşi lucru: că scrisoarea trimisă ierahilor are un conţinut religios, pe care 1 -a scris în urma unei vedenii şi numai destinatarii ştiu de aceste lucruri ${ }^{60}$. Nimic mai mult.

56 ACNSAS, fond Penal, dosar 126777, vol. 3, f. 8; Ibidem, vol. 1, f. 3; Ibidem, vol. 2 , f. 46.

${ }^{57}$ Ibidem, vol. 1, ff. 9-10.

58 Ibidem, f. 11.

${ }^{59}$ IDEM, fond Informativ, dosar 181347, vol. 4, f. 8.

${ }^{60}$ IDEM, fond Penal, dosar 126777, vol. 1, ff. 12-12v. 
Următoarea anchetă este consemnată la 23 noiembrie. Faţă de interogatoriul precedent, apare numele rectorului I. Gh. Coman, despre care a relatat momentul în care a fost chemat de către acesta, când 1-a atenţionat să nu mai difuzeze şi să nu discute cu nimeni despre această scrisoare ${ }^{61}$.

La 25 noiembrie este luat din nou în anchetă. Se reiau aceleaşi aspecte din interogatoriile precedente. Potrivit mărturiei pe care a dat-o ulterior, în episoadele de anchetă, marcate deseori de acte de tortură şi intimidare (ex. „mă izbeau de pereţi”, ,,îmi dădeau cu picioarele la fluierele picioarelor" etc.), pentru a semna aşa cum consemna anchetatorul, părintele Mina a fost interogat asupra relaţiei pe care o avea cu profesorul Dumitru Stăniloae şi cu membri ai Rugului Aprins, precum părintele Benedict Ghiuş.

Nemulţumit de evoluţia anchetei, prin care căuta eventuali complici, anchetatorul Tîrlea Ion insistă asupra conţinutului scrisorii, căutând să-l acuze pe părintele Mina de exprimări ostile la adresa regimului, precum: „Noi, creştinii zilelor noastre, avem fericirea că am cunoscut pe Hristos, Fiul lui Dumnezeu, dar avem o mare nefericire şi trăim zile grele de când a venit potrivnicul lui Hristos de care s-a spus că va veni”. Pentru anchetator exprimarea „trăim zile grele” a constituit un cap de acuzare, pentru ca mai apoi să consemneze în procesul-verbal, conform limbajului specific anchetatorilor: „Prin aceste cuvinte, eu [Mina Dobzeu, n. ANP] am prezentat în mod ireal faptul că actualul regim ar căuta să distrugă credinţa în Dumnezeu şi din cauza aceea, eu am scris că «trăim zile grele»" $" 62$.

Anchetatorul merge mai departe şi devine chiar hermeneutul unui pasaj din scrisoare: „Căci trei sunt care lucrează acest negativism: balaurul (Satana), fiara (filosofia veacului acestuia) şi proorocul mincinos (omul fărădelegii) sau Antihristul propriu-zis. Şi iată aceste profeţii s-au împlinit în zilele noastre". În mod evident, că hermeneutul consemnează explicaţia în dreptul părintelui: „Subsemnatul, prin aceasta, a calomniat filosofia ateistă,

${ }^{61}$ Ibidem, ff. 13-13v.

${ }^{62}$ Ibidem, ff. 14-15v. 
spunând că oamenii care nu cred în Dumnezeu sunt oamenii «fărădelegii» şi «mincinoşi». Când am scris că filosofia acestui veac ar fi fiară, m-am referit şi la filosofia materialistă, spunând că aceasta ar fi ca o fiară care sfâşie sufletele şi conştiinţa oamenilor"63.

Pe 27 noiembrie s-au consemnat interogatoriile a trei profesori de la Institut, adică Ene Branişte, Vladimir Prelipcean şi Mircea Chialda. Procesele-verbale sunt scurte, de nici măcar o pagină, cu un limbaj specific textelor din anchetele Securităţii, cu termeni precum: „calomnie”, „escrocherie”, „conţinut duşmănos”, „a documenta”. Alături de acestea se regăsesc şi erori, care nu puteau proveni de la teologi, precum: ,ierarhia monahală”, „oameni «credincioşi»»". Apoi, în toate cele trei interogatorii persistă ideile de îndemnare a clerului la „,nesupunerea” faţă de legile statului şi de revoltă la adresa regimului comunist, ai cărui conducători sunt văzuţi de Mina Dobzeu ca „fiare sălbatice”. Ba mai mult, apare chiar expresia „trăim vremuri grele”, în interogatoriul consemnat profesorului M. Chialda.

Din aceste motive este greu de decelat între autenticitatea afirmaţiilor şi intruziunile anchetatorului în procesele-verbale consemnate martorilor.

Totuşi, există pasaje, care provin din declaraţiile martorilor. De exemplu, în interogatoriul profesorului Mircea Chialda se vorbeşte despre cum, „în toamna anului 1959”, prorectorul Nicolae Nicolaescu 1-a trimis la Departament pentru a prelua o copie a scrisorii lui Mina Dobzeu, pe care a studiat-o, iar ,,apoi, spune el, am propus exmatricularea sa din Institut şi să fie înştiinţate organele de stat despre atitudinea sa duşmănoasă regimului democrat-popular din RPR". Probabil că ultima parte a afirmaţiei, cea legată de denunţ, este o interpolare a anchetatorului. Însă, în anchetă apare problema sancţionării părintelui Mina, care, cel puţin înainte de arestarea sa, nu era enunţată în corespondenţa dintre Institut-DepartamentSecuritate, la care am făcut referire până acum. M. Chialda şi E.

\section{${ }^{63}$ Ibidem.}


Branişte menţionează despre exmatricularea părintelui Mina din Institut, iar V1. Prelipcean adaugă faptul că ,a fost judecat pentru abateri de la disciplina monahală" ${ }^{64}$.

Pe 12 decembrie, părintele Mina este din nou luat în anchetă. I se consemnează două interogatorii, în care este întrebat asupra conţinutului scrisorii pe exemplarele trimise mitropolitului Vasile Lăzărescu al Timişoarei şi Patriarhului Justinian. Părintele Mina îşi reafirmă poziţia, anume că scrisoarea a fost scrisă numai de el şi că are „numai conţinut religios” bazat pe vedeniile sale din $1959^{65}$.

Acestea au fost ultimele interogatorii. La 24 decembrie 1959 anchetatorul a redactat ,concluziile de învinuire”, etapă procedurală de trimitere în justiţie. Evident că acuzaţia nu a fost modificată, ci doar confirmată de probele strânse la dosar: interogatoriile care i sau luat părintelui Mina şi martorilor, alături de procesul-verbal de la ancheta făcută în Institutul Teologic (din 1 septembrie 1959) şi scrisoarea trimisă ierarhilor cu expertiza grafoscopică, procedură practic inutilă a Securităţii, deoarece inculpatul recunoscuse paternitatea corpului delict, probabil pentru a îngroşa dosarul ce urma să ajungă în instanţă.

Procesul s-a desfăşurat în ziua de 9 februarie 1960 la Tribunalul Militar Bucureşti. În depoziţia sa, părintele Mina a reiterat cele afirmate în anchetă, nimic mai mult.

Martorii se pare că au avut o atitudine nuanţată. Deşi în depoziţia scrisă s-a consemnat că îşi ,menţin declaraţiile de la anchetă şi concluziile făcute prin procesul-verbal întocmit de Institutul Teologic, aflat la dosar”, Ene Branişte a afirmat că în scrisoarea respectivă Mina Dobzeu „defăimează autoritatea bisericească precum şi regimul din RPR. S-au luat măsurile corespunzătoare prin eliminarea lui din Institut. În celelalte acţiuni ale inculpatului acesta a avut o comportare normală, fiind serios şi

${ }^{64}$ Ibidem, ff. 18-20v. În stadiul actual al cercetărilor nu ştim la ce fel de ,judecată" se face referire.

${ }^{65}$ Ibidem, ff. 16-17v. Plicurile şi cele două exemplare ale scrisorii, alături de cea trimisă Episcopului Andrei Magieru se află la dosarul penal (Ibidem, ff. 27-28v, 68-70v, 111-114). 
ascultător, atât ca student, cât şi ca monah"66. La fel se exprimă şi V1. Prelipcean, pe când M. Chialda adaugă: „Pentru noi a fost o surpriză. Se comporta normal şi se bucura de autoritate între colegii lui. Inculpatul era printre studenţii mediocri. $\mathrm{Nu}$ m-am gândit niciodată că ar suferi de vreo boală, întrucât avea o comportare normală" ${ }^{\prime 67}$.

Sentința nu este dată în aceeaşi zi, ci amânată pentru ziua de 11 februarie. Împotriva sa, instanţa a reţinut faptul că scrisoarea are „un conţinut duşmănos regimului din ţara noastră, dând o interpretare ostilă unor texte biblice, pretinzând că Biserica în acest regim ar trece prin clipe grele şi suferinţă, îndemnând pe conducătorii Bisericii şi întreg clerul ortodox la rezistenţă pentru apărarea credinței, la nesupunere faţă de regim, [...] aducând totodată calomnii la adresa orânduirii democrat-populare, [...] făcând astfel agitaţie din care putea rezulta un pericol pentru securitatea statului" 68 .

Astfel, prin Sentinţa nr. 37 din 11 februarie 1960, părintele Mina este condamnat la 7 ani închisoare corecţională şi 4 ani interdicţie corecţională ${ }^{69}$.

Ulterior, părintele Mina solicită recurs, conform procedurii normale în justiţie, pentru următoarele motive: „1) nerespectarea legii. Scrisoarea pentru care am fost condamnat este cu un conţinut religios, deci e o problemă bisericească şi trebuie să fiu judecat de un tribunal bisericesc. 2) Martorii acuzatori n-au studiat în fond conţinutul scrisorii, luându-o superficial [şi] mi-au adus învinuiri ce nu sunt în scrisoare. 3) Fiind o scrisoare pe care am scris-o în urma vedeniilor şi pe bază de studiul Sfintei Scripturi, scrisoarea nu e duşmănoasă regimului, deoarece Dumnezeu nu duşmăneşte pe oameni, chiar şi atunci când îi mustră şi îi ceartă cu cuvinte aspre, ca să-i îndrepteze. 4) În procesul înscenat nu mi s-a dat voie la martori ai apărării, prin care să dovedesc că n-am dus

\footnotetext{
66 Ibidem, f. 52.

${ }^{67}$ Ibidem, f. 54.

68 Ibidem, f. 60.

${ }^{69}$ Ibidem, ff. 56-57.
} 
nicio activitate duşmănoasă împotriva regimului" "70. În această perioadă, părintele Mina se afla în penitenciarul Jilava.

Primul termen de judecată la instanţa de recurs a fost stabilit pentru data de 10 martie. Apărarea a invocat nelegalitatea şi netemeinicia hotărârii iniţiale, pe motiv că instanţa de fond nu şi-a exercitat din plin rolul său activ, potrivit Codului de procedură penală, adică ,nu a dispus efectuarea unei expertize neuropsihice pentru a stabili gradul de responsabilitate penală a inculpatului". Tribunalul, verificând actele de la dosar, mai ales scrisoarea în cauză şi declaraţiile inculpatului, constată ,o îndoială cu privire la discernământul inculpatului”, motiv pentru care se impune „o atentă supraveghere medicală". Pe acest motiv principal, instanţa admite cererea de recurs ${ }^{71}$.

Însă, abia la 14 martie 1960, prin Decizia nr. 396 a Tribunalului Militar Bucureşti, Colegiul de Recurs casează sentinţa iniţială, acceptă recursul solicitat de părintele Mina şi dispune ,,internarea inculpatului în spitalul Văcărești, pentru a fi supus unei expertize neuropsihice de către Serviciul medico-judiciar al Capitalei"72.

Efectuarea acestei expertize medicale va trena, mai ales din cauza faptului că părintele Mina nu era transferat de la Jilava la Văcăreşti. Abia pe 19 aprilie 1960 se face expertiza, în urma căreia se concluzionează: „Numitul este responsabil de faptele comise. Socotim că ar putea să se ţină seama de misticismul său la aprecierea vinovăţiei sale" 73 .

După înfăţişarea din 27 aprilie, prin Decizia nr. 658 din 30 aprilie 1960 a Tribunalului Militar Bucureşti, părintele Mina este condamnat la 7 ani închisoare corecţională şi 4 ani interdicţie corecţională, confirmându-se astfel sentinţa iniţială $\breve{T}^{74}$.

\footnotetext{
${ }^{70}$ Ibidem, ff. 96-96v.

${ }^{71}$ Ibidem, ff. 72-72v.

72 Ibidem, f. 73.

${ }^{73}$ Ibidem, ff. 83-84.

${ }^{74}$ Ibidem, f. 89.
} 


\section{Detenția}

Conform dosarului de penitenciar, parcursul părintelui Mina în detenţie, după ancheta de la Ministerul Afacerilor Interne, a fost următorul: Jilava (17 februarie - 23 aprilie 1960), Văcăreşti (12 aprilie 1960), Salcia-Ostrov (14 noiembrie 1960), Giurgeni (10 aprilie 1962), Periprava (20 mai 1962) şi Gherla (17 decembrie $1962)^{75}$. La 24 iunie 1964 a fost eliberat din Formaţiunea 0606, adică penitenciarul Gherla ${ }^{76}$. În timpul detenţiei, pe fişa medicală, la rubrica diagnostic, s-a consemnat „delir mistic”, în urma expertizei medicale efectuate la spitalul-penitenciar Văcăreşti ${ }^{77}$. La 11 februarie 1962, la Periprava i s-a depistat o ,debilitate fizică generală", care s-a perpetuat timp de un an, motiv pentru care a fost considerat, ,inapt"

În perioada 30 octombrie 1961 - 7 decembrie 1962, pe când se afla la Ostrov, a primit 6 pachete a câte $5 \mathrm{~kg}$ de la Vasile Vieru, gazda sa de la Brădiceşti ${ }^{79}$. Într-o însemnare aflată în arhiva personală, părintele Mina spune că primul pachet pe care 1-a primit în detenţie a venit din partea Episcopului Teofil Herineanu, prin Vasile Vieru.

Despre traiul cotidian din penitenciar avem câteva mărturii. Prima ar fi de la Nicu Steinhardt, care în Jurnalul fericirii spune: „De altfel, totul aici, la Jilava, are cel mai violent aspect de puşcărie, de pârnaie, nu de temniţă gravă. Clădirea e sinistră, dar interiorul celulei aduce a iarmaroc, a tablou de Breughel, Chagall, a balamuc. Mărcuţa. E o aglomeraţie de neconceput, abia te poţi mişca, gălăgia e formidabilă, deşi se vorbeşte numai în şoapte (cel puţin teoretic), coada la tinetă e

\footnotetext{
${ }^{75}$ https://www.iiccr.ro/fise-matricole-nou/?drawer=Fise $\% 20$ matricole $\% 20$ penale

\%20-\%20Detinuti\%20politici*D*D\%2003.\%20Dinca\%20-\%20Doltu*Dobzeu \%20Mihail(Mina) (consultat la 10.10.2019).

76 ACNSAS, fond Penal, dosar 126777, vol. 2, ff. 1-2.

${ }^{77}$ Ibidem, ff. 4-5.

${ }^{78}$ Ibidem, f. 6v.

${ }^{79}$ Ibidem, f. $11 \mathrm{v}$.
} 
neîntreruptă, circulă întrebările cele mai năstruşnice (,,cum se spune cintezoi pe franţuzeşte?" $)^{80}$.

Tot despre Jilava, din mai 1960, avem relatarea aceluiaşi $\mathrm{N}$. Steinhardt: „Căratul tinetelor la Jilava ia, când ele sunt pline ochi, aspecte jalnice şi caraghioase. Cea mai neînsemnată mişcare neconformă cu echilibristica salturilor de pe trapez poate avea drept consecinţă răsturnarea conţinutului vasului îndeobşte cunoscut sub numele de «tun». Cad în repetate rânduri la «scoaterea serviciilor» alături de părintele Mina. El e îndemânatec, eu nu. Se întâmplă să se reverse tunul. Pedepsele în cazul acesta sunt aspre. La iuţeală punem spurcăciunea jos şi ne repezim să adunăm fecalele şi să ştergem cu degetele sau cu batistele urmele de lichid. Uneori izbutim, alteori nu. Părintele Mina lucrează atât de repede încât mie îmi rămâne puţin de făcut. Pedepsele, alături de părintele Mina, îşi pierd caracterul sordid şi iau aspect de mortificare. Apoi, cuviosul nu e numai monah, ci şi ţăran mucalit. Râde atât de sincer, încât mă învăţ şi eu să fac haz mare de adunarea rahaţilor" ${ }^{\prime 1}$.

În iulie 1981, într-o discuţie despre lipsa alimentelor în detenţie, părintele Mina afirma: „Eu sunt obişnuit să rezist la astfel de crize; îmi place să fiu modest, dar e bine să ai în casă ce-ţi trebuie. Mulţi m-au întrebat cum am rezistat eu în condiţiile grele din detenţie; eram foarte bolnăvicios, dar am rezistat, căci eram obişnuit cu muncă, mâncare puţină; când observam că nu mai rezist, că sunt slăbit, mă retrăgeam de la muncă... Ei te mai presau, te mânau la muncă, te treceau printr-o comisie medicală şi stabileau cine mai poate munci sau nu; alimentaţia era foarte slabă; am fost dat la munci grele, la roabă, la săpat, dar după ce s-a stabilit că nu mai sunt de roabă, m-au dat la munci mai uşoare, la grădini, unde munceam câte 2-3 luni pe vară" ${ }^{\prime 2}$.

${ }^{80}$ N. STEINHARDT, Jurnalul fericirii, postfaţă şi repere bio-bibliografice de Virgil Bulat, Edit. Mănăstirii Rohia, 2005, p. 87.

${ }^{81}$ Ibidem, p. 364.

${ }^{82}$ ACNSAS, fond Informativ, dosar 181347, vol. 9, f. 39. 
Astfel ajungem la perioada Salcia, despre care avem mărturia unui coleg de suferinţă, Doru Novacovici, care descrie modul cum a slujit părintele Mina Dobzeu cu părintele Vasile Vasilache la marele praznc al Paştilor: „La 17 aprilie au fost Sf. Paşti. În celulă aveam doi preoţi, pe părintele Vasilachi şi pe călugărul-preot Dobzeu. Ne-am strâns în ajun în jurul lor şi cu glasul în surdină am cântat «Hristos a înviat». Părintele Vasilachi fusese vicar la Patriarhie şi secretar al Patriarhului Nicodim. Se ocupa de slujbele transmise pe vremuri la radio de la Sf. Patriarhie. Era un om excepţional, de mare cultură, cum rar am întâlnit printre preoţii ortodocşi. Preotul Dobzeu era un habotnic, care toată ziua se ruga. El era un alt gen de om, mai simplu, dar cu multă dragoste pentru credinţa lui Dumnezeu. Amândoi aveau un glas vibrant şi cald, atunci când se rugau sau cântau. $\mathrm{Cu}$ orice risc, i-am rugat să facă slujba de Sf. Paşti. Unii mai în vârstă au obiectat, spunând că nu-i bine să-i supărăm pe gardieni. Eu am spus că, dacă este să luăm bătaie sau să fim ţinuţi cu burta pe ciment, acest lucru se poate petrece şi dacă nu se face slujbă. Până la urmă au fost de acord să se facă slujbă, căci Dumnezeu ne va ajuta şi nu ni se va întâmpla nimic. Slujba a avut loc în două etape, înainte şi imediat după «număr», spre a deruta pe gardieni. Slujba ţinută de părintele Vasilachi şi călugărul Dobzeu a fost înălţătoare şi cred că n-am s-o uit. Această slujbă s-a întipărit în sufletul meu pentru totdeauna. Totul s-a petrecut în linişte, toată lumea a fost mulţumită şi la ora 22, când s-a dat stingerea, toţi au adormit cu mîinile împreunate într-o rugăciune tăcută către Domnul nostru Iisus, Mântuitorul tuturor celor în suferinţă" 83 .

\section{Botezul lui Nicu Steinhardt}

Nicolae Steinhardt, cunoscut drept unul dintre intelectualii de marcă ai României, apropiat grupului Noica, fusese arestat la

83 Doru Novacovicı, În România, după gratii, Buzău, Fundaţia pentru tineret, [f.a.], p. 78-79. 
31 decembrie 1959 pentru că refuzase să devină martor al acuzării împotriva prietenilor săi. Abia fusese condamnat pe nedrept la 12 ani de muncă silnică, în timp ce Mina Dobzeu primise 7 ani de închisoare. Momentul întâlnirii celor doi este redat de mai multe ori de către Mina Dobzeu, dar şi de $\mathrm{N}$. Steinhardt. El spune foarte clar că Steinhardt a venit în celula 18 din penitenciarul Jilava şi îşi căuta un loc în care să doarmă peste noapte (7 martie 1960). Monahul Mina a fost cel care i-a întins mâna, oferindu-i loc, lângă el, pe patul pe care îl avea la etajul trei ${ }^{84}$. Abia dimineaţă au făcut cunoştinţă, părintele Mina manifestând deschidere faţă de evreul aspirant la creştinism, după cum însuşi Steinhardt mărturiseşte: „Călugărul meu e basarabean. E un om tânăr, condamnat pentru că ar fi avut vedenii şi a trimis Departamentului Cultelor o scrisoare în care protesta împotriva desfiinţării schitului unde vieţuise. Abia apuc - bat fierul cât e cald - să-i spun că sunt ovreu şi că doresc a mă boteza, că se şi arată de acord. E blajin, cu gesturi domoale, şi tăcut. [...] Părintele Mina, călugărul ortodox, mi-a impus numai câteva lecţii de catehizare şi le facem şezând pe marginea unui pat de fier, cu spatele spre uşă, unul lângă altul, vorbind în şoapte. Suntem, fireşte, amândoi în uniformă de puşcăriaş: bocanci fără şireturi, zeghe vărgată $(\mathrm{CR})$ şi giorsită, boneţică (de data aceasta cu dungile orizontale) pe cap. Vestonul nu are nasturi, pantalonii, prea scurţi, stau gata să cadă.

[...] 10-15 martie 1960. Lecţiile de catehizare merg foarte repede; părintele Mina e îngăduitor şi nepretenţios şi e drept că şi eu mă dovedesc a cunoaşte destul de multe. Cei trei preoţi se sfătuiesc între ei, apoi vin să mă întrebe ce vreau să fiu, catolic sau ortodox? Le răspund fără şovăială că ortodox. Foarte bine. Mă va boteza călugărul. Dar cei doi greco-catolici vor asista la botez şi ca un omagiu la credinţa lor şi, ca o dovadă că înţelegem cu toţii a da viaţă ecumenismului într-o vreme în care Ioan al XXIII-lea e pe tronul pontifical, voi rosti crezul în faţa preoţilor catolici. Toţi trei îmi cer să mă consider botezat în numele

${ }^{84}$ Nicolae STEINHARDT, Jurnalul fericirii, p. 84-85. 
ecumenicităţii şi să făgăduiesc a lupta - dacă-mi va fi dat să ies din închisoare - pentru cauza ecumenismului, mereu. Ceea ce făgăduiesc din toată inima.

[...] 15 martie 1960. Catehizarea a luat sfârşit. Botezul, hotărât pentru ziua de cincisprezece, are loc aşa cum stabilisem. Părintele Mina alege momentul pe care-l socoteşte cel mai potrivit: la întoarcerea «de la aer», când caralii sunt mai ocupaţi, când agitaţia e maximă. Trebuie să lucrăm repede şi să acţionăm clandestin în văzul tuturor. Conspiraţia în plină zi a lui Wells. Ceva în genul manevrelor invizibile ale lui Antonov-Ovseienko. $\mathrm{Eu}$ unul nu voi ieşi la plimbare (lucru uşor, deoarece m-a ros bocancul şi am o umflătură purulentă pe laba piciorului drept. La infirmerie n-am izbutit să fiu dus, cu toate că mă prezint în fiecare dimineaţă la raport. Doctorii Răileanu şi Al-G. mă tratează aplicându-mi pe «bubă» un ştergar muiat în apă viermănoasă din ciubăr. $\mathrm{Cu}$ o zi înainte, un plutonier mi-a spus că «nici mort» nu mă duce la medicul oficial. Căile Domnului, ocolite).

Rămân deci singur vreun sfert de oră cât durează «aerul», adică aproape singur, căci mai sunt câţiva scutiţi de plimbare pentru felurite pricini. Pustiită de zarvă şi forfotă, camera ia un aspect şi mai ciudat, ca o scenă goală în care grămezile de recuzite îşi găsesc sălaşul la nimereală. Dar mai ales deosebirea sonoră faţă de camera plină este atât de izbitoare, încât am impresia unei tăceri absolute tăcerea devine, vorba lui Cervantes, un spectacol - şi mă pot linişti, reculege niţel.

Când puhoiul de oameni se întoarce cu zgomot mare, ducând în rând de câte doi balia, ciubărul, tineta şi un «rezervor» cu apă, părintele Mina, fără a-şi scoate mantaua, dă buzna la singura căniţă din cameră - e o căniţă roşie, cu smalţul sărit, neclătită şi respingătoare - şi o umple cu apă viermănoasă proaspăt adusă în «rezervorul» purtat de el şi de un alt deţinut. Vin la patul meu şi cei doi preoţi greco-catolici şi naşul. Naş mi l-am ales cu vreo câteva zile înainte pe Em[anuel] V[idraşcu], fost avocat şi profesor, bun cunoscător de latină şi greacă, trimis în judecată pentru a fi redactat ordinul de zi: «Vă ordon, treceţi Prutul». V. a fost directorul de cabinet al lui Ică [Antonescu] şi a purtat cu maşina lui la tipografie 
faimosul ordin pe care pentru nimic în lume orgoliosul şi altminteri foarte cultul general [Ion] Antonescu nu ar fi îngăduit altcuiva să-1 scrie în numele său. De ce l-am ales pe V. pe care nu-l cunoşteam înainte (ca de altfel pe cei mai mulţi din oamenii alături de care am complotat) şi nu pe Al. Pal. - un vechi prieten, mă rog, prieten din 54, dar spirist şi el, şi apoi luasem hotărârea de a ne considera prieteni din copilărie - ori pe dr. Al. G. a cărui personalitate mă impresionase atât de puternic, care a şi rămas pentru mine fiinţa cea mai desăvârşit multilaterală pe care am întâlnit-o în puşcărie şi omul cel mai dăruit cu virtutea curajului - Marinică P. a fost cel mai bun, la el bunătatea prefăcându-se prin intensitate şi în inteligenţă şi în tact şi în politeţe şi în rafinament şi în putere de judecată, dar totul la un nivel mai lipsit de grandoare - ori pe vreunul din generală prezenţi (nu m-ar fi refuzat) ori pe blândul Toto Enescu, nu ştiu să spun.

Doi dintre deţinuţi, complici, trec în dreptul vizetei, s-o astupe. S-ar putea în orice clipă să vină gardianul să se uite, dar acum când celulele, pe rând, sunt scoase la plimbare ori aduse înapoi, e puţin probabil. La repezeală, dar cu acea iscusinţă preoţească unde iuţeala nu stânjeneşte dicţia desluşită - părintele Mina rosteşte cuvintele trebuincioase, mă înseamnă cu semnul crucii, îmi toarnă pe cap şi pe umeri tot conţinutul ibricului (căniţa e un fel de ibric bont) şi mă botează în numele Tatălui şi al Fiului şi al Sfântului Duh. De spovedit, m-am spovedit sumar: botezul şterge toate păcatele. Mă nasc din nou, din apă viermănoasă şi din duh rapid.

Trecem apoi, oarecum liniştiţi, oarecum uşuraţi - hoţul care nu-i prins în fapt e om cinstit - la patul unuia dintre preoţii grecocatolici: e lângă tinetă şi balie (am coborât cu toţii de la cucurigu) şi acolo recit crezul (ortodox), după cum fusese stabilit. Reînoiesc făgăduinţa de a nu uita că am fost botezat sub pecetea ecumenismului. Gata. Botezul, în asemenea împrejurări, e perfect valabil şi fără de cufundare şi fără de mirungere (dacă voi ajunge să scap din închisoare cu bine, urmează, pentru taina mirungerii, să mă prezint la un preot al cărui nume îmi este dat de părintele Mina; numele acesta aveam să-1 uit şi apoi să mi-l reamintesc). 
Ritmul intens al celulei nr. 18 ne înşfacă imediat. Părinţii greco-catolici sunt de serviciu pe cameră. Părintele Mina are de spălat o cămaşă.

[...] Aprilie 1960, viaţa de mănăstire (şi poartă rasa de când era flăcăiandru) 1-a pregătit de minune pe călugăr pentru închisoare şi 1-a învăţat ceea ce este esenţial pentru a răbda: să ştii să taci, să nu te mire şi să nu te necăjească nimic, să fii surd, să fiii hotărât a îndura totul fără a crâcni (fără a cârti zic monahii) cu o egalitate oarbă şi încăpăţânată având drept ideal nepăsarea, de nu chiar nesimţirea. Iar dintre acestea cele mai mari sunt: tăcerea şi nepăsarea. Textul biblic (Iacov 3,2) - în care se afirmă că cine-şi poate înfrâna gura îşi poate înfrâna trupul întreg şi toată fiinţa - are un caracter ştiinţific şi experimental întru nimic inferior al unuia de, să zicem, Claude Bernard" $" 85$.

După ieşirea din închisoare, la îndemnul părintelui Mina, Nicu Steinhardt a mers la Institutul Teologic din Bucureşti, paraclisul „Sf. Ecaterina”, pentru a primi mirungerea de la „părintele Teodorescu”. Nu 1-a găsit la paraclisul universitar, ci la Schitul Darvari, unde Nicu Steinhardt a primit Sfântul Mir în prezenţa naşului său din închisoare, avocatul Emanuel Vidraşcu ${ }^{86}$.

După ieşirea din închisoare între cei doi s-a cultivat o frumoasă prietenie, între cel care era monah şi cel care aspira la monahism. În semn de recunoștință, în fiecare an de 15 martie, data botezului său, Nicolae Steinhardt obişnuia să-i trimită o felicitare părintelui Mina.

\section{În loc de concluzii}

Studiul de faţă este o parte dintr-un demers mai amplu de investigare pe tema vieții și activităţii Părintelui Mina Dobzeu în lumina documentelor de arhivă și a mărturiilor oferite de contemporani. Este un demers care reflectă în perspectivă critică

\footnotetext{
${ }^{85}$ Ibidem, p. 86-91, 145.

${ }^{86}$ M. Dobzeu, Am fost duhovnicul lui Ceauşescu, p. 39.
} 
şi obiectivă, pornind de la sursele istorice, trecutul tumultuos al unuia dintre miile de călugări și călugărițe, care au cunoscut provocările regimului comunist din România. Totodată, Mina Dobzeu este călugărul care a luptat consecvent împotriva comunismului încă de la instalare. Și nu a făcut-o dintr-o bravură, ci convins de faptul că luptă împotriva unei ideologii distructive la adresa Bisericii.

$\cos 80$

\section{Bibliografie}

\section{Izvoare inedite}

1. AARB, fond Cancelarie, dosar 43/1952, 3/1954, 6/1955, 2/1959, 27/1960.

2. ACNSAS, fond Informativ: dosar 4049, vol. 2; dosar 181347, vol. $1-4,6,9$.

3. ACNSAS, fond Penal, dosar 21363, vol. 1-2; 126777, vol. 1-3.

4. AEH, fond personal Mina Dobzeu, dosar 21.

5. AEH, fond Protoieria Huşi, dosar personal Dobzeu Mina.

6. AEH, fond Schitul Brădiceşti, dosar 1/1946.

7. ANIC, fond Ministerul Cultelor şi Artelor-Direcţia Studii, dosar 22/1951.

8. A.Prot.Dej, Dosar personal Mina Dobzeu-Parohia Jimbor.

9. ASTN, dosar 4/1954 și 3/1955.

\section{Izvoare edite}

10. CIRA, Călin Emilian, Convorbiri despre N. Steinhardt, prefaţă de Ion Pintea, Eikon, 2010.

11. DobzeU, Mina, Am fost duhovnicul lui Ceauşescu, ed. îngr. şi cuvânt înainte de Fabian Anton, Cluj-Napoca, Edit. Dacia, [2002].

12. IDEM, „Prin pronia divină Nicolae Steinhardt este o mână întinsă către intelectuali”, în Vestitorul Ortodoxiei, an IX, nr. 177-178, aprilie 1997, p. 2.

13. IDEM, Trei strigări împotriva lui Antihrist. Istoria adevărată a pustnicului de la Brădiceşti, Edit. Anastasia, 1999.

14. IANCU, Vasile, Interviu. „Balaurul roşu de la Răsărit a venit”, în România literară,

nr.

$3 / 2008$ 
http://arhiva.romlit.ro/index.pl/arhimandritul_mina_dobzeubalaur ul_rou_de_la_rsrit_a_venit?caut=balaurul\%20rosu, consultat la 02.10.2019).

15. Novacovici, Doru, In România, după gratii, Buzău, Fundaţia pentru tineret, [s.a.]

16. PĂRĂIAN, Teofil, Amintiri despre duhovnicii pe care i-am cunoscut, Cluj Napoca, Editura Teognost, 2003.

17. Petcu, Adrian Nicolae, LuCHIAN, Nicolae Cătălin (eds.), Episcopul Grigorie Leu în vâltoarea istoriei. Documente (19241949), Iaşi, Edit. Doxologia, 2019.

18. STEINHARDT, Nicolae, Jurnalul fericirii, postfaţă şi repere biobibliografice de Virgil Bulat, Edit. Mănăstirii Rohia, 2005.

\section{Lucrări speciale:}

19. CODRESCU, Răzvan, „Părintele Mina Dobzeu. Cu Steinhardt şi dincolo de Steinhardt", în Rost, an VI, nr. 65, iulie 2008, p. 3639.

20. DobZeU, Mina, „În temniţele Satanei. Întâlnirea cu N. Steinhardt”, în Rost, an VI, nr. 65, iulie 2008, p. 40-43.

21. Moldovan, Silviu B., „Mina Dobzeu între răspândirea de «manifeste subversive» şi «subversiune» prin manifestare în Spirit", în vol. Despre «baltici». Ipostaze ale represiunii politice în România postbelică, Bucureşti, Edit. Eikon, 2018, p. 229-238.

\section{Lucrări generale:}

22. Clit, Costin, Mănăstirea Brădiceşti, Iaşi, Edit. Doxologia, 2013.

23. PeTCU, Adrian Nicolae, „Închisorile Arhimandritului Vasile Vasilache", în Mărturisitori ai Ortodoxiei în timpul regimului comunist. Studii şi evocări, Mihail-Simion SĂSĂUJAN coord., Bucureşti, Edit. Cuvântul vieţii a Mitropoliei Muntenie şi Dobrogei, 2018, p. 277-330.

24. IDEM, „Decretul 410/1959 de la adoptare la aplicare”, în vol. Biserică şi stat. Perspective istorice şi teologice. Studii în memoria Părintelui Profesor Adrian Gabor, V. A. CARABĂ, S. L. NAZÂRU şi I. Al. TUDORIE eds., Brăila, Edit. Istros, 2019, p. 523560.

25. The Imprisoned Church. Romania, 1944-1989, INST, Bucharest, 1999. 


\section{Abrevieri:}

AARB-Arhiva Arhiepiscopiei Romanului și Bacăului ACNSAS-Arhiva CNSAS

AEH-Arhiva Episcopiei Huşilor

ANIC-Arhivele Naționale Istorice Centrale

A.Prot.Dej-Arhiva Protoieriei Dej

ASTN-Arhiva Seminarului Teologic Neamț 